\title{
Feminist Children: A Purple Cow? ${ }^{*}$
}

\author{
Phyllis A. Katz \\ Institute for Research on Social Problems, North Miami, USA \\ Email: phyllis@pakatz.com
}

How to cite this paper: Katz. P. A. (2019), Feminist Children: A Purple Cow? $A d$ vances in Applied Sociology, 9, 505-515. https://doi.org/10.4236/aasoci.2019.911037

Received: October 3, 2019

Accepted: November 9, 2019

Published: November 12, 2019

Copyright $\odot 2019$ by author(s) and Scientific Research Publishing Inc. This work is licensed under the Creative Commons Attribution International License (CC BY 4.0).

http://creativecommons.org/licenses/by/4.0/

\begin{abstract}
Three questions are addressed with regard to raising feminist children: The first is why we should try to instill feminism, the second is what our goals should be, and the third is how best to accomplish them. Considering how the concept of feminism might be operationalized in children, we draw from both general observations and ideas, as well as empirical data. The data are drawn from a longitudinal study of over 200 children that began when they were six months of age, and continued for 5-1/2 years. Results show that despite the over-determined and inevitable learning of gender stereotypes, even young children vary in the degree to which they subscribe to stereotypes.
\end{abstract}

\section{Keywords}

Gender, Stereotypes, Feminism, Child Development

I never saw a Purple Cow,

I never hope to see one;

But I can tell you, anyhow,

I'd rather see than be one (Burgess, 1895; 2013).

\section{Why Try to Raise Feminist Children?}

The majority of Americans believe that traditional sex-role socialization of children is important and necessary. Underlying this opinion (for many) is the belief that gender differences are innate. It would follow, then, that male and female brains should reflect this. In a recent review of this research, however, Rippon (2019), a neuroscientist, concluded that the results were inconsistent, and that those differences that have been obtained were more likely due to differential treatment of boys and girls rather than to inborn structural differences.

Even without strong evidence that gender differences are innate, however, considerable resistance to change exists. Why, then, bother to try? What are the

\footnotetext{
*This paper draws from some material previously presented (Katz, 2003).
} 
reasons to change this?

These reasons span a variety of fields including history, economics, sociology, and psychology.

Feminism is the belief in full social, political and economic equality for women (Steinem, 1994). While we have made considerable progress towards these goals, we still remain far short of reaching them. And the very concept of feminism has been ridiculed, caricatured and attacked, both by those who prefer the status quo, and those who believe (wrongly) that we no longer need this concept because the goals have been achieved.

Many of our feminist foremothers of the last three centuries fought against gender discrimination and extolled the benefits of feminism to society, benefits that remain relevant. The following quotes from early feminists provide vivid examples. Just three years after the US Constitution were ratified, Mary Wollstonecraft, for example, noted:

Would man but generously snap our chains, and be content with rational fellowship instead of slavish obedience, they would find us more observant daughters, more affectionate sisters, more faithful wives, more reasonable mothers, in a word, better citizens (Wollstonecraft, 1792/1993: p. 121).

Right after the Civil War, Sojourner Truth spoke of the negative consequences of gender inequality. Advocating voting rights for women, she noted:

There is a great stir about colored men getting their rights, but not a word about the colored women; and if colored men get their rights, and not colored women theirs, you see the colored men will be masters over the women, and it will be just as bad as it was before (Truth, 1867/1993: p. 166).

Susan B. Anthony wrote, at the end of the nineteenth century, of how equal participation of women would result in both improved family relations and increased productivity when she said:

The day will come when men will recognize woman as his peer, not only at the fireside but in the councils of the nation. Then, and not until then, will there be the perfect comradeship, the ideal union between the sexes that shall result in the highest development of the race (Anthony, 1897/1993: p. 189).

Finally, comparable sentiments were echoed by one of the most brilliant women of the twentieth century, Simone de Beauvoir, in her penetrating analysis The Second Sex, where she stated that:

When we abolish the slavery of half of humanity, together with the whole system of hypocrisy that it implies, then the "division" of humanity will reveal its genuine significance and the human couple will find its true form

(De Beauvoir, 1953/1993: p. 352).

And she even said it earlier in French: 
Ending inequality and improving female-male relationships continue to be lofty reasons for raising feminists. There are many others. One is simply to stop women from being shortchanged. Another reason is to stop sexual stereotypes from becoming "psychological straitjackets for both sexes" (Komarovsky, 1953).

The impact of feminism on society has already been revolutionary, and we should not lose sight of its central tenets. The enemy of feminism is not differences of opinion (which can be healthy) but sexism. Sexism is an "ism" that antedates feminism. For many centuries, proponents of sexism espoused the belief that females are inferior to males, and treated them as if they were. More politically correct contemporary sexists give lip service to gender equality, but still maintain a sexist status quo. This more modern form of sexism (Swim, Aikin, Hall, \& Hunter, 1995) is no less damaging to women than its older counterpart. The form of "benevolent sexism" has been found to relate to a number of things, including how people evaluate women's competence (Cassidy \& Krendl, 2019). It is important, therefore, that we articulate and model the basic precepts of feminism to succeeding generations of children and adolescents.

\section{What Would Feminist Children Be Like?}

What should our goals be? Can parents and educators possibly change things so as to make children less sexist?

My alternative history avatar, Sadie, thinks so. Sadie was King Solomon's favorite wife, and was discussed in several recent papers (Katz, 1988). Sadie was best known for trying to talk Solomon out of his supposedly "wise" suggestion that an infant claimed by two mothers be cut in half, with one half going to each woman. Fortunately, the real mother immediately offered the still-intact baby to the other woman.

This biblical parable is extraordinarily implausible for a number of reasons. First, why would two women be making claim to the same infant? A biological mother would surely know whether or not it was her infant. Second, the proposed solution was very violent. What if neither woman had spoken, or one of them fainted. Little known to history was that Solomon had discussed this problem earlier with Sadie, who recommended a different solution. Sadie thought that the women knew who the mother was, and they were merely stand-ins for the two men who each claimed paternity. She suggested putting the two potential fathers in a small, unventilated room with the baby and making them stay there until one evidenced willingness to change the baby's diaper. While they both liked this idea, Solomon went with the earlier scenario because of the possibility that neither man would ever change the diaper. Sadie told Solomon the two women about the scenario in advance so that they could rehearse their lines.

Sadie and Solomon also wrestled with the sexism problem. They had eleven children. Their four oldest sons wanted to be soldiers, and their four oldest daughters wanted to get married and have children. Sadie told Solomon that she 
thought this was boring and potentially dangerous. She wanted more female advisors to help run the kingdom and temper the men's warlike urges. Couldn't they do something different with their three remaining children? Being a wise woman, Sadie suggested that if they wanted to change things, they had to figure out why they were so good at raising mothers and soldiers in the first place. Perhaps it was necessary to first understand why things were the way they were.

Well, Sadie was right. We remain remarkably successful in raising sex-stereotyped children. Sex role socialization is pervasive and ubiquitous, and no one is immune. It begins at birth for the child and continues through young adulthood (Katz, 1986; Katz \& Winiarski, 2013).

To exemplify how early in life this is observable, we did a study (Seavey, Katz, \& Zalk, 1975), that introduced a six-month-old to adults as "Johnny", "Jane", or "I can't remember which baby this is" (the Baby X condition). Despite the fact that we used the same infant for all three conditions, adults chose toys based on the gender they thought the baby was (dolls for Jane, footballs for Johnny, and confusion with Baby X). This study was replicated by us and by others. Thus, gender cues, even if inaccurate, are remarkably salient. Are adults capable of changing their stereotype-inducing behavior?

Well, Sadie thought they could. As she said to Solomon "all we have to do is look at these stupid nursery rhymes we read to children. Little Miss Muffet gets frightened by spiders, so how will she ever be a biologist? Little girls are supposed to be made of sugar and spice, so how can they become lawyers? Jack Sprat's wife doesn't even have a name, but we know her eating habits, and they're unhealthy. Jill follows Jack blindly, even when he's falling down a hill. Mary with her little lamb is the only rebel of the group, but she is laughed at-Can she stand the pressure? I think we should have our scribe engrave new nursery tablets".

Well, Sadie, as usual, was on to something. Can children be feminist even if we do not change nursery rhymes, as she suggested? We looked at this issue in 200 families and their children, beginning when the children were six months of age and followed them until they were 72 months. Half the samples were Euro American and half African American. Children were assessed with a variety of non-verbal and verbal measures at seven different age levels (6 months, 12 months, 18 months, 24 months, 36 months, 60 months and 72 months), including perceptual habituation, sorting, toy play, labeling and toy preferences. Parents were assessed with regard to their socialization techniques, gender attitudes, and a variety of other relevant indicators (more elaborate description of the measures can be found in Katz \& Kofkin, 1997).

Perhaps the most interesting about the gender curriculum is how very early it starts. To demonstrate, we found that almost $90 \%$ of the children can clearly distinguish male from female faces at six months of age. They not only make the visual discrimination, but they also demonstrate the existence of a preverbal concept of gender. 
We demonstrated this through the use of a visual habituation task. The infant was shown a series of same-sex faces (e.g. four different women or four different men). Infant attention waned with each successive face, i.e., they habituated. When we changed the gender of the person in the picture, their looking time increased dramatically (dishabituation). This tells us that the infant is responding not simply to novelty, but to the category.

After they display this preverbal gender concept, they learn may other gender-related skills. These are summarized in Table 1. Interestingly, much of this learning antedates their being toilet trained!

As can be seen in the results presented in Table 1, a surprisingly large part of basic gender learning is completed before the third year of life. At two years of age, the majority of the children could label themselves correctly as a boy or a girl, and many could correctly use gender-related nouns and pronouns and sort pictures and dolls on the basis of gender cues. At three, they already exhibited

Table 1. Percentages of children showing gender-related behavior.

\begin{tabular}{|c|c|c|c|c|}
\hline \multirow{2}{*}{ Task } & \multicolumn{4}{|c|}{ Age of child (in months) } \\
\hline & 18 mos. & 24 mos. & 30 mos. & 36 mos. \\
\hline \multicolumn{5}{|l|}{ Cognitive skills } \\
\hline Gender self-labeling (percentage correct) & & $68 \%$ & $88 \%^{\mathrm{a}}$ & $93 \%^{\mathrm{d}}$ \\
\hline Labeling of friend & & $43 \%$ & $37 \%^{\mathrm{b}}$ & $39 \%^{\mathrm{b}}$ \\
\hline Nonverbal sorting (placing pictures in boxes) & $48 \%$ & $56 \%^{\mathrm{a}, \mathrm{d}}$ & $69 \%^{\mathrm{a}}$ & $84 \%$ \\
\hline Sorting to verbal cues & $22 \%$ & $67 \%$ & $90 \%$ & $96 \%$ \\
\hline \multicolumn{5}{|l|}{ Correct use of gender words } \\
\hline Mom/Dad & & $98 \%$ & $97 \%^{\mathrm{c}}$ & $100 \%$ \\
\hline Boy/Girl & & $75 \%{ }^{\mathrm{d}}$ & $88 \%^{\mathrm{d}}$ & $98 \%$ \\
\hline Man/Woman & & $53 \%^{\mathrm{d}}$ & $79 \%^{\mathrm{d}}$ & $94 \%$ \\
\hline $\mathrm{He} / \mathrm{She}$ & & $42 \%^{\mathrm{a}}$ & $79 \%^{a}$ & $91 \%$ \\
\hline Her/Him & & $27 \%^{a}$ & $63 \%^{\mathrm{a}, \mathrm{d}}$ & $83 \%$ \\
\hline \multicolumn{5}{|l|}{ Stereotype learning } \\
\hline Clothes (percentage identifying correctly) & & $37 \%^{\mathrm{a}}$ & $59 \%^{\mathrm{a}}$ & $74 \%$ \\
\hline Toys & & $24 \%$ & $38 \%$ & $53 \%$ \\
\hline Tasks & & - & $32 \%^{\mathrm{c}}$ & $39 \%^{\mathrm{c}}$ \\
\hline Occupations & & - & $27 \% \%^{\mathrm{b}, \mathrm{c}}$ & $35 \%^{\mathrm{b}, \mathrm{c}}$ \\
\hline \multicolumn{5}{|l|}{ Preference behavior } \\
\hline Percentage of time spent with same-sex toys & $32 \%$ & $42 \%^{\mathrm{a}}$ & $45 \%^{\mathrm{a}}$ & $62 \%$ \\
\hline Percentage of time spent with other-sex toys & $25 \%$ & $25 \%$ & $25 \%^{\mathrm{a}}$ & $21 \%^{\mathrm{a}}$ \\
\hline Percentage same-sex photo choice as playmate & & & $33 \%$ & $52 \%$ \\
\hline Sex of actual playmates (percentage same sex) & & $57 \%{ }^{\mathrm{b}}$ & $67 \%^{\mathrm{b}}$ & $73 \%$ \\
\hline
\end{tabular}

${ }^{a}$ Girls are significantly higher than boys. ${ }^{b}$ Boys are significantly higher than girls. ${ }^{~ B l a c k ~ c h i l d r e n ~ a r e ~ s i g n i f-~}$ icantly higher than Whites. ${ }^{\mathrm{d}}$ White children are significantly higher than Blacks. 
same-sex toy and playmate preferences. Thus, awareness of gender differences and the basics of gender identity are already present at three years of age.

Does this early awareness inevitably lead to subsequent differences? Is it possible for children to adopt a "different but equal" position? Can little boys and girls be content in their newly articulated maleness or femaleness without associating it with gender stereotypes or denigrating the other group? Perhaps, but there are many factors that maintain gender stereotyping that work against such an outcome.

It is not only the content of gender learning that is important, but also the process itself and its consequences. The very act of social categorization divides the world in an "us" and a "them" which has a number of cognitive and perceptual consequences (e.g. Sherif, 1982; Tajfel \& Turner, 1979). These include a tendency to perceive similarities among persons categorized under one label and to magnify differences between those with different labels. As a result, it becomes easier to evaluate individuals in the "them" group more negatively. This linguistic division is not, of course, restricted to gender differences. We see the same phenomenon with race labels (Katz, 1973; Katz, Sohn, \& Zalk, 1975) and even with less socially meaningful imposed linguistic categories.

While adults are susceptible to the effects of these linguistic differentiations, young children may be even more strongly affected. Once learned, stereotypes become expectations that influence how we see and judge others, making it easy to perpetuate sexism.

Furthermore, such stereotypic gender beliefs can easily become self-fulfilling prophecies (e.g. Geis, 1993). There are three stages in this process. If you begin with the belief that women and men will behave differently, you will see them behaving differently. You will consequently treat them differently. Finally, because of this differential treatment, they may indeed start to exhibit the very behavioral differences you expected-but because of the differential treatment, not because they were there originally. This self-fulfilling prophecy scenario may be particularly prominent in child rearing.

To summarize, we know that children learn about gender at tender ages, and that various distortions, perhaps partially unconscious, predispose parents and children to maximize gender-category differences. These are formidable obstacles to raising feminist children.

\section{How Might Raising Feminist Children Occur?}

What are we striving for when we talk about raising feminist children? We can readily define what feminism looks like in adolescents and adults, but is there such a thing as a feminist child?

There have been at least two approaches suggested for how to raise incipient feminists. The more radical approach is to aim for the elimination of behavioral gender differences and their associated stereotypes. This is the Baby $\mathrm{X}$ approach. The second approach is to accept the existence of societally defined gender 
differences, but to reduce their importance, value female and male characteristics equally, and aim for a gender-flexible child as the developmental forerunner of a future feminist.

The first approach, while ideologically satisfying to some, is not very realistic. It would be almost impossible to make gender cues completely irrelevant, and there would be many who would be against this. Even if parents tried to do this, they are not the only influence with regard to content of gender identity, e.g. there are other children, media, other adults, etc.

The second approach, reducing the salience of gender, is more feasible. A gender-flexible child is the most promising candidate to become a future feminist. Flexibility involves choosing activities on the basis of individual likes and skills rather than on the basis of stereotypes.

What kinds of factors are related to raising a gender-flexible or nongenderstereotyped child? A number of individual and situational factors have been mentioned as possible correlates (see Katz, 1979, 1986 for greater detail).

These influences vary as a function of developmental level (e.g. Katz \& Ksansnak, 1994). For the first six years of life, parents are the most significant influences. They can impact gender-role learning along many dimensions. They can directly reinforce and encourage gender-stereotyped behavior or not. They can control the child's physical and social environment. They can provide a wide array of books, media and toys that permit the child to explore many varied activities or expose the child to a mostly sex-stereotyped environment. They themselves also model different types of gender-related behaviors for the child. Additionally, their personalities and attitudes relevant to gender may also influence gender socialization. Playmates and nursery school curriculum may also play a role, but parents typically influence these factors as well.

During grade school, peers take on a more significant socialization role, as do the child's teacher, the school curriculum and the amount and types of media exposure. For adolescents, the role of parents becomes less pronounced as both same-sex and opposite-sex peers become more prominent. Television, movies, social media and school curriculum and atmosphere also play important roles.

\section{Correlates of Gender Flexibility in the Preschool Years}

Because much of a child's gender learning has been completed by 6 years of age, these early years appear to be the most promising to focus on. If we want more feminist children, we need to do something different with children long before they enter school.

In the longitudinal study previously referred to, we were interested in what differentiated stereotyped from flexible children at both three and five years of age. Flexibility was operationalized as a composite of toy choices, doll play, and playmate choice of unfamiliar children (photos), as well as actual friendship choices as reported by the parents. We looked at many types of parent behaviors. Since the testing was conducted in the child's home, we were also able to rate the 
children's toys and room decor with regard to the degree of gender stereotyping. Some of the results have been published in more detail elsewhere (Katz \& Kofkin, 1997, Katz \& Winiarski, 2013). What will be presented here, therefore, is a summary of the major trends.

At three years of age, we found that a child's gender preferences (whether stereotyped or not) were related to: 1) household activity patterns; 2) general style of parenting; 3) level of gender learning; 4) gender of the child; and 5) race of the child. Our most gender-flexible 3-year-old lived in households where the division of domestic tasks was less stereotyped than average (e.g. fathers engaged in more childcare; taking out the garbage not always masculine task, etc.). More gender-flexible children had parents who granted their children more independence and were less demanding, less authoritarian, and warmer than were parents of more sex-typed children. Young children are affected by who they see doing what within their household, and how they are treated.

Several child characteristics also affected flexibility. Children who were most proficient with regard to gender-related cognitive skills were also more likely to have more sex-typed preferences. At 3 years of age, such cognitive proficiency was unrelated to either IQ or parental education levels. Gender and race also were correlated with gender flexibility at 3 . Boys were more flexible than girls are at this age level, in contrast with later ages. Black boys were more gender flexible than White boys were.

At 5 years of age, there were differing correlates. It should be noted that although children become considerably more knowledgeable about sex-role stereotypes (see Table 1 ) than they were at 3 , there is still considerable variability in how sex-typed they are. The factors affecting gender flexibility at 5 include: 1) household activity patterns; 2) family attitudes and behavior; 3) physical environment; 4) developmental level; 5) gender; and 6) race.

The first factor, household activity levels, was also relevant for the children two years earlier. The second factor, family attitudes and behavior overlaps with this, but includes other variables such as how parents socialize their children with regard to gender. In a household where the father is the sole breadwinner and the mother is primarily responsible for household chores, for example, a child may believe that each sex can only perform certain tasks, which leads to more stereotyped behavior and less flexibility. In contrast, if the child is raised in an environment where responsibilities are shared (i.e. both work outside the home, both cook and clean, etc.), the child develops more fluid gender roles. Parental expectations and socialization practices play a role. Parents who minimize sex typing with regard to playing activities and future aspirations have more flexible children.

A significant predictor at 5 was how stereotyped their rooms and toys were. As expected, the more stereotyped the rooms, the less gender-flexible were the children. Boys were more affected by this variable, and their rooms and toys were generally more stereotyped than girls. Such environments are, of course, 
determined by the parents. Interestingly, parental gender attitudes did not always match what was going on in their homes. They might verbalize very liberal gender-role attitudes, but often have very stereotyped rooms for their child.

Three child variables affected the results. Children at 5 are more knowledgeable about sex-role stereotypes than they were at three, and some children were less flexible as a result. In contrast to the gender differences at 3 (i.e., boys more flexible), girls show much more flexibility at 5 , a finding that continues throughout childhood. Significant differences between black children and white children were also found. In general, white children were more sex-stereotyped than were black children.

Although not related to the longitudinal study, several additional factors discussed in the literature also appear to be related. One is family composition (Katz, 1987): Only-child girls are the most gender-flexible (Katz \& Boswell, 1984), and those from two-child families with opposite-sex siblings are more flexible than those with same-sex siblings. We have previously suggested that this latter finding may be attributable to a broader array of toys available. Sibling composition was not specifically investigated in the longitudinal study because all the children were fist-born.

\section{Conclusion}

In summary, these various findings show that there are both stereotyped and flexible children. Thus, feminist children (i.e., gender-flexible) do exist, albeit in the minority, unlike the "Purple Cow" analogy at the outset. Like charity, incipient feminism begins in the home environment. The toys and activities children engage with the household patterns they observe, and the kinds of behaviors their parents encourage or discourage are the major determinants of their gender-flexible behavior patterns. The role of parents is a key. Young children are not likely to develop gender flexibility on their own because most other socialization sources reinforce stereotyped behavior.

Well, if our friend Sadie knew about these findings, she would probably say, "Feminism begins at home". Speaking of Sadie, I recently learned that they were successful in instilling feminism in two of their children. Their daughter Naomi was interested in rocks. When she wanted to become a mining engineer, they didn't laugh (although everyone else did). Naomi displayed an uncanny knack for discovering precious metals and stones, which added greatly to the wealth of King Solomon's mines. Then everyone stopped laughing.

Their son Jacob was never interested in rocks or in athletics. His favorite activity was to hang around the kitchen and help out. Since Sadie did not permit the cooks to throw him out, his culinary talents developed and blossomed. I heard that he opened the first Nouvelle Kosher restaurant in Jerusalem, and people came from afar just to taste his star-shaped gefilte-fish pizza.

Unfortunately, we don't know what they did to accomplish this. Sadie never left us her stone engravings on this topic, and that may be why it is taking so 
long to discover their secrets.

\section{Conflicts of Interest}

The author declares no conflicts of interest regarding the publication of this paper.

\section{References}

Anthony, S. B. (1897). The Status of Women, Past Present and Future. The Arena. As Quoted in Partnow, E. (1993), The New Quotable Woman (p. 842). New York: Penguin Books.

Burgess, G. (1895). Purple Cow. In the Lark, No. 1 (p. 1915). New York: Charles Scribner's Sons.

Cassidy, B. S., \& Krendl, A. C. (2019). A Crisis of Competence: Benevolent Sexism Affects Evaluations of Women's Competence. Sex Roles, 81, 505-520.

https://doi.org/10.1007/s11199-019-1011-3

De Beauvoir, S. (1953). The Second Sex. As Quoted in Partnow, E. (1993), The New Quotable Woman (p. 352). New York: Penguin Books.

Geis, F. L. (1993). Self-Fulfilling Prophecies: A Social Psychological View of Gender. In A. E. Beall, \& R. J. Sternberg (Eds), The Psychology of Gender (pp. 9-54). New York: Guilford Press.

Katz, P. A., Sohn, L., \& Zalk, S. R. (1975). Perceptual Concomitants of Racial Attitudes in Urban Grade School Children. Developmental Psychology, 11, 135-144. https://doi.org/10.1037/h0076446

Katz, P. A. (1973). Perception of Racial Cues in Preschool Children: A New Look. Developmental Psychology, 8, 295-299. https://doi.org/10.1037/h0034146

Katz, P. A. (1979). The Development of Female Identity. Sex Roles, 5, 155-178. https://doi.org/10.1007/BF00287928

Katz, P. A. (1986). Gender Identity: Development and Consequences. In R. D. Ashmore, \& F. K. Del Boca (Eds.), The Social Psychology of Female-Male Relations: A Critical Analysis of Central Concepts (pp. 21-67). Orlando, FL: Academic Press. https://doi.org/10.1016/B978-0-12-065280-8.50007-5

Katz, P. A. (1987). Family Constellation: Effects on Gender Schemata. In L. S. Liben, \& M. Signorella (Eds.), Children's Gender Concepts: New Directions in Child Development (pp. 39-56). San Francisco, CA: Jossey-Bass. https://doi.org/10.1002/cd.23219873805

Katz, P. A., \& Boswell, S. L. (1984). Sex-Role Development and the One-Child Family. In T. Falbo (Ed.), The Single-Child Family (pp. 63-116). New York: Guilford Press.

Katz, P. A. (1988). Children and Social Issues. Journal of Social Issues, 44, 193-209. https://doi.org/10.1111/j.1540-4560.1988.tb02058.x

Katz, P. A., \& Ksansnak, K. R. (1994). Developmental Aspects of Gender-Role Behavior in Childhood and Adolescence. Developmental Psychology, 30, 272-282. https://doi.org/10.1037//0012-1649.30.2.272

Katz, P. A., \& Kofkin, J. A. (1997). Race, Gender and Young Children. In S. S. Luthar, J. A. Burack, D. Cicchetti, \& J. Weisz (Eds.), Developmental Psychopathology: Perspectives on Adjustment, Risk, and Disorder (pp. 51-74). Cambridge: Cambridge University Press.

Katz, P. A. (2003). Racists or Tolerant Multiculturalists: How Do They Begin? American Psychologist, 58, 897-909. https://doi.org/10.1037/0003-066X.58.11.897b 
Katz, P., \& Winiarski, A. (2013). Sex Role Stereotypes and Gender Differences. Encyclopedia of Diversity in Education, 1948-1958. Sage: California.

Komarovsky, M. (1953). Women in the Modern World. Boston: Little Brown. As Quoted in Partnow, E. (1993). The New Quotable Woman (p. 448). New York: Penguin.

Rippon, R. (2019). Gender and Our Brain: How New Neuroscience Explodes the Myths of the Male and Female Minds. New York: Pantheon.

Seavey, C. A., Katz, P. A., \& Zalk, S. R. (1975). Baby X: The Effect of Gender Labels on Adult Responses to Infants. Sex Roles, 1, 103-109. https://doi.org/10.1007/BF00288004

Sherif, C. W. (1982). Needed Concepts in the Study of Gender Identity. Psychology of Women Quarterly, 6, 375-398. https://doi.org/10.1111/j.1471-6402.1982.tb01067.x

Steinem, G. (1994). Moving beyond Words. New York: Simon \& Schuster.

Swim, J. K., Aikin, K. J., Hall, W. S., \& Hunter, B. A. (1995). Sexism and Racism: Old-Fashioned and Modern Prejudiced. Journal of Personality and Social Psychology, 68, 199-214. https://doi.org/10.1037/0022-3514.68.2.199

Truth, S. (1867). Speech Given at the Annual Meeting of Equal Rights, New York City. As Quoted in Partnow, E. (1993). The New Quotable Woman (p. 166). New York: Penguin.

Tajfel, H., \& Turner, J. C. (1979). An Integrative Theory of Intergroup Conflict. In W. G. Austin, \& S. Worchel (Eds.), The Social Psychology of Intergroup Relations (pp. 33-37). Monterey, CA: Brooks/Cole.

Wollstonecraft, M. (1792) Of the Pernicious Effects which Arise from the Unnatural Distinctions Established in Society. As Quoted in Partnow, E. (1993). The New Quotable Woman (p. 121). New York: Penguin. 